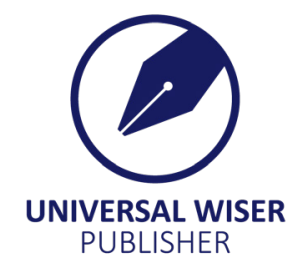

\title{
Evaluating the Effect of Studying Computer Ethics and Computer Ethics Rules and Regulations on Computer Ethics at Work
}

\author{
Yas A. Alsultanny \\ Arab German Academy for Science and Technology, Germany \\ Email: alsultanny@hotmail.com
}

\begin{abstract}
With the increasing reliance on computer and Internet, the danger of cybercrime attacks was increased. This research paper aims to evaluate the effect of studying computer ethics and computer ethics rules and regulations on computer ethics at work. A self-administrated questionnaire was designed for data collection. The data was collected from 374 responds working in private and public sectors. The results showed a strong correlation between studying computer ethics and computer ethics rules and regulations, a strong correlation between studying computer ethics and computer ethics at work, and a moderate correlation between computer ethics rules and regulations and computer ethics at work. The gender and age have statistically significant effect on computer ethics at work, while education level and job position have no statistically significant effect on computer ethics at work. According to the respond's opinions, this paper recommends giving intensively interest in educating the computer ethics modules, to all levels of education as well as organizing continuous learning workshops to employees for all job positions, to increase awareness against computer crimes. Keywords: internet, computer ethics, education level, cybercrime, computer crimes, continuous learning
\end{abstract}

\section{Introduction}

Internet has become an essential technology for communication, online conferencing, online teaching, and many others areas of applications. At the same time, increasing concerns about ethical issues created by the interconnecting world in the age of globalization. These concerns about privacy, misuse of computer resources, and even criminal activity abound are threatened all individuals, organizations, countries, and economies.

Computer ethics is rapidly developing and evolving into a wider and even more important field, thus it, reasonably,

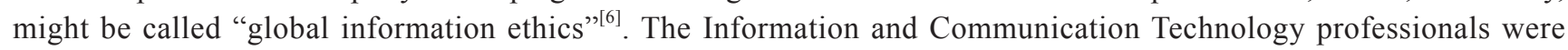
described the computer ethics concept through providing unethical computer using behavior. They considered computer ethics primarily as a component of Internet ethic ${ }^{[24]}$. Many of the news has focused on unethical accounting practices, thus the importance of computer ethics has also increased. In addition, issues such as Internet privacy, computer crime, intellectual property controversies, censorship, consumer trust, and other factors are at the forefront of business today ${ }^{[23]}$. Computer fraud cannot be prevented even with an improved risk control system and strengthening of computer security systems, this illustrates the need of good computer ethics and ethical behavior, the computer crime is a continuously increasing problem across the world ${ }^{[25]}$. The traditional face to face learning ethics might not be applicable to online and distance learning environments due to the ethical issue fraud ${ }^{[1]}$.

The computer ethics play a key role in all internet applications in preventing frauds. This paper was for evaluating the effect of studying computer ethics and computer ethics rules and regulations on computer ethics at work in the Kingdom of Bahrain. The next sections of this paper are organized as follows; the section outlines the motivations for this study, the section presents the research objectives, the section of related literature, the section of research model and methodology, the section of data analysis and discussion, and finally a section of the conclusion.

\section{Motivations for this research}

The motivations for this research emerge from the recommendations that appeared in the literature of the absence of cybercrime law in Bahrain and the disappearance of computer ethics from the university's curriculum, which increased the danger of computer crimes. 
The Central Bank of Bahrain announced that some customer noticed a breakthrough to their bank accounts by rigging Automated Teller Machine (ATM) cards and credit cards, where the number of cards that were affected 174 cards $^{[9]}$. In 2012, Interior Ministry's cybercrime unit in Bahrain recorded a total of 223 cases related to cybercrime, while in 2011 the number of cases recorded was 249 .

Thus, it is certainly worthwhile to investigate the following significances in this paper;

1. Create awareness and help in reducing cybercrimes.

2. Increasing the level of computer ethics by pointing out the weaknesses in the organizations.

3. Improve the computer ethics rules and regulations by pointing out the weaknesses of current rules and regulations.

\section{Research objectives}

The major objectives of this research paper are concerned with answering the following questions;

1. What is the effect of studying computer ethics on computer ethics rules and regulations?

2. What is the effect of studying computer ethics on computer ethics at work?

3. What is the effect of computer ethics rules and regulations on computer ethics at work?

4. Is the demographic information (gender, age, education level, and job position) having statistically significant differences on computer ethics at work?

\section{Computer ethics literature review}

In mid-1970s, Walter Maner began to use the term "computer ethics" "[]]. In 1985, Moor published his known-classic article "What is Computer Ethics?"[28]. In that same year, Deborah Johnson published "Computer Ethics" which was the first textbook in this field ${ }^{[20]}$. Information ethics is about the critical reflection on the visions and options for better lives in the digital age, not only about norms ${ }^{[8]}$. The proper control measure should be applied upon identifying the unethical behavior in order to transfer the negative behavior to a more positive behavior. This will be the basement to create a code of computer ethics especially for countries with deficiencies in computer ethics ${ }^{[4]}$. Security professionals should prevent, detect, and manage malicious insider activity and risk by producing empirically derived results from insider and outsider computer criminal activity ${ }^{[1]]}$. There are two common threats, firstly, the rise of 'hacktivists' or cyber terrorists. The second threat is cybercrime ${ }^{[13,39]}$.

The dependence on information technology needs a higher standard of cyber security to maintain the availability and integrity of the essential services such as e-banking. This increased the demand skilled for cyber professionals ${ }^{[3]}$.

The Internet and cyberspace are shared between everyone in the world, thus all countries should collaborate, at the international level, to counter the broad range of threats ${ }^{[37]}$. The lists of definitions of the most popular types of computer crimes are sorted alphabetically in Table 1. 
Table 1. Most popular computer crimes

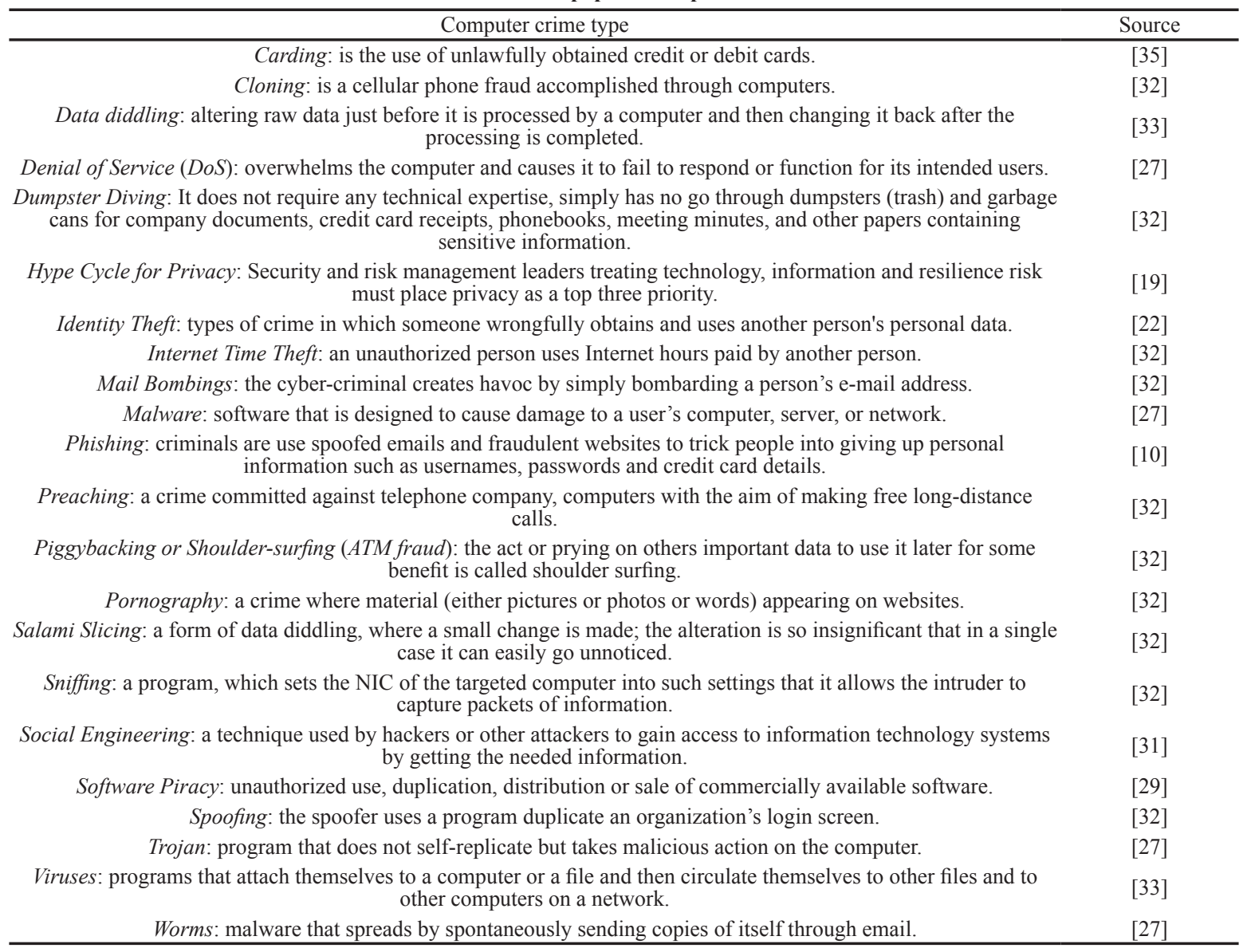

Computer crimes are generally classified into six categories. These categories are military and intelligence attacks, business attacks, financial attacks, terrorist attacks, grudge attacks, and thrill attacks ${ }^{[38]}$.

The number of cybercrime victims is 378 million per year and exceeding a million per day, this indicated for every second there are 12 victims. Furthermore, the global cost of cybercrimes was $\$ 113$ billion; this indicated that half of online adults have been suffered from cybercrimes and/or negative online situations in the past year. Moreover, $41 \%$ of them attacked by malware, viruses, hacking, scams, fraud and theft ${ }^{[30]}$. Best practices on cybercrime prevention need the cooperation across the private sector, communities, government, and internationally. In addition, those good practices must include the promulgation of legislation, effective leadership, the development of criminal justice and law enforcement capacity, education and awareness, the development of a strong knowledge base $\mathrm{e}^{[42]}$.

To successfully reduce threat, multidisciplinary approach was suggested by involving education of the cyber-citizens and the high-tech $\mathrm{CEOs}^{[26,41]}$. Dolado ${ }^{[15]}$ found that the computer ethics courses affect the computer ethics of the students, because their feedback on these courses was positive. Ben-Jacob ${ }^{[5]}$ found that the integration of the technology in our lives makes the computer ethics education critical. Many studies recommended computer ethics rules and regulations development to reduce cybercrimes ${ }^{[2,15,36-37]}$, their studies showed the importance of computer ethics rules and regulations to help organizations in reducing cybercrimes.

Information technology (IT) plays a major role in reducing the threats and preventing cybercrimes ${ }^{[17]}$. All vulnerable businesses using IT such as; banks, insurance, communications/media, defiance contractors, health care, technology, highprofile businesses, financial institutions and governments are at high risk, because of cybercrimes compared to the risks in other sectors ${ }^{[18,40]}$.

\section{Research model and methodology}

This paper depends on self-administrated questionnaire. According to Ryu ${ }^{[34]}$ questionnaires are often regarded as an inexpensive and convenient way to collect data from a large number of participants. According to Fanning ${ }^{[16]}$ survey questionnaire is used to collect measurable data from a specific group of people. 
The questionnaire was based on the knowledge gained from surveying several literatures (see Table 2). It includes three dimensions, which are studying computer ethics, computer ethics rules and regulations, and computer ethics at work.

Table 2. Literature related computer ethics factors

\begin{tabular}{cc}
\hline Computer ethics factors & Supported literature \\
\hline Studying computer ethics & {$[15] ;[5] ;[3]$} \\
Computer ethics rules and regulations & {$[15] ;[2] ;[39]$} \\
Computer ethics at work & {$[15] ;[18]$} \\
\hline
\end{tabular}

The conceptual model of computer ethics factors is shown in Figure 1. The questionnaire consists of two parts, the first part was for demographic information and questions concerning general information; the second part consists of 14 statements divided into three factors measuring the computer ethics. To answer the questions of this paper the following hypotheses were designed.

$\mathrm{H}_{1}$ : Studying computer ethics have an effect on computer ethics rules and regulations.

$\mathrm{H}_{2}$ : Studying computer ethics have an effect on computer ethics at work.

$\mathrm{H}_{3}$ : Computer ethics rules and regulations have an effect on computer ethics at work.

$\mathrm{H}_{4}$ : Demographic information (gender, age, education level, and job position) have statistically significant differences on computer ethics at work.

Questionnaire was validated before using it to test the research hypotheses. The questionnaire statements constructed on a five-point Likert scales with end points of strongly disagree and strongly agree. To collect data 370 copies of the questionnaires were distributed online and 85 in paper form. The number of online received responses were 321 and 53 were received from the paper version. The total respondents were 374 .

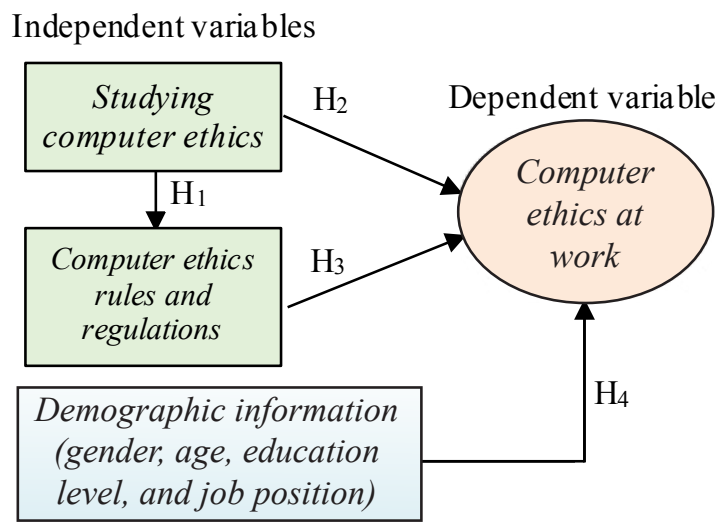

Figure 1. Conceptual research model

The correlation or effect factor between the dimensions calculated to measure the direction and the degree of correlation or effect factor that is rated between -1 and +1 . The positive values mean positive correlation or effect factor, while the negative values mean negative correlation or effect factor. Table 3 shows the scale of 5 levels used to measure the strength of the correlation or effect factor as follows ${ }^{[44]}$.

Table 3. Interpreting strengths of correlations

\begin{tabular}{ccc}
\hline $\mathrm{N}$ & Correlation value & Interpretation \\
\hline 1 & \pm .70 or higher & Very strong correlation \\
2 & $\pm<.70$ to \pm .40 & Strong correlation \\
3 & $\pm<.40$ to \pm .30 & Moderate correlation \\
4 & $\pm<.30$ to \pm .20 & Weak correlation \\
5 & $\pm<.20$ to \pm .01 & No or negligible correlation \\
\hline
\end{tabular}

Source: http://faculty. Quinnipiac.edu/libarts/polsci/Statistics.html

There are many methods for estimating questionnaire reliability, that measures the internal consistency of 
questionnaire statements. Cronbach's alpha was selected in testing the questionnaire reliability. The test was held to each dimension and for the total statements of the questionnaire. According to $\mathrm{Wang}^{[43]}$, the dimension with alpha coefficient value of 0.6 and above will be considered reliable. The results of testing the questionnaire by Chronbach's Alpha showed that all the factors (dimensions) are above 0.6 , with overall reliability of 0.822 .

\section{Data analysis and discussion}

\subsection{Descriptive analysis}

The three dimensions of the questionnaire were analyzed by using SPSS. The first dimension is studying computer ethics, which consists of 5 statements. The second dimension is computer ethics rules and regulations that contain 5 statements. The last dimension is computer ethics at work, which consists of 4 statements. Table 4 summarizes averages, standard deviations (SD), and ranking the statements.

The first dimension measured studying computer ethics, the highest responses, was for S1: "Early study of computer ethics will help the new generation to use computer ethically" with an average value of 4.26 and standard deviation 0.877 . The dimension average is 4.038 with standard deviation of 0.956 , which is falling in the agree degree of agreement. From this dimension, it appears that the respondents agreed on the importance of studying computer ethics. In addition, this is what Kizza ${ }^{[21]}$ argued, that studying computer ethics, including an ethical framework is an argent need. Moreover, the studying computer ethics is a long-term investment, especially in the youth to build their character and guide their actions.

The second dimension measured computer ethics rules and regulations, the highest responses is for S10 "Financial department is the most targeted by computer criminals" with average value of 4.24 and standard deviation of 0.869 . The dimension average is 3.848 and standard deviation of 1.013, which is falling in the agree degree of agreement. From the results, it is clear that the respondents agreed on the importance of rules and regulations in financial department and they strongly agreed that the financial department is the most targeted department by computer criminals. They, also, agreed that even if there is availability and awareness of professional codes, norms, laws, etc., many professionals will act unethically, this is clear from S9. And this is what Sembok ${ }^{[36]}$ recommended, establishment of up-to-date, common, and mutually supporting cyber-laws to fight against crimes toward the creation of cybercrime free information society.

The third dimension measured the computer ethics at work, the highest responses is on $\mathrm{S} 14$ "It is more secure if the network security is updated frequently" with an average value of 4.32 and standard deviation of 0.815 . The dimension average is 3.818 with standard deviation of 1.031, which is falling in the agree degree of agreement. From the results, it is clear that S13 "It is easier to find a job if I declare that I act ethically in the professional environment" got the lowest average. This indicates that the responds have low awareness of computer ethics in the financial department. 
Table 4. Averages and standard deviations of the questionnaire statements

\begin{tabular}{|c|c|c|c|c|c|}
\hline Dimension & Statement No. & Statement & Average & $\mathrm{SD}^{*}$ & Rank \\
\hline \multirow{6}{*}{$\begin{array}{l}\text { Studying } \\
\text { computer } \\
\text { ethics }\end{array}$} & $\mathrm{S} 1$ & $\begin{array}{l}\text { Early study of computer ethics will help the new generation to use } \\
\text { computer ethically. }\end{array}$ & 4.26 & 0.877 & 1 \\
\hline & $\mathrm{S} 2$ & $\begin{array}{l}\text { I recommend studying computer ethics course as mandatory course in } \\
\text { schools and universities curriculum. }\end{array}$ & 4.04 & 0.990 & 2 \\
\hline & $\mathrm{S} 3$ & Computer ethics study will reduce the computer crimes. & 3.95 & 1.017 & 5 \\
\hline & S4 & It is important to teach computer ethics by lectures or workshops. & 3.95 & 0.922 & 4 \\
\hline & S5 & Learning computer ethics is useful, in my work. & 3.99 & 0.975 & 3 \\
\hline & & $1^{\text {st }}$ dimension average & 4.038 & 0.956 & - \\
\hline \multirow{6}{*}{$\begin{array}{l}\text { Computer } \\
\text { Ethics } \\
\text { Rules and } \\
\text { Regulations }\end{array}$} & S6 & $\begin{array}{l}\text { The agreement to safely use the computer guarantees the rights and } \\
\text { safety of the parties. }\end{array}$ & 3.90 & 1.002 & 3 \\
\hline & S7 & $\begin{array}{c}\text { Commitment to the rules and regulations will reduce the work of } \\
\text { computer crime. }\end{array}$ & 4.16 & 0.883 & 2 \\
\hline & S8 & $\begin{array}{c}\text { The only important thing with respect to the professional behavior is the } \\
\text { awareness of the law. The ethical aspect is a secondary aspect, unless it } \\
\text { has legal consequences. }\end{array}$ & 3.36 & 1.238 & 5 \\
\hline & S9 & $\begin{array}{l}\text { Many professionals will continue to act unethically, even if there is } \\
\text { availability and awareness of professional codes, norms, laws, etc. }\end{array}$ & 3.58 & 1.075 & 4 \\
\hline & $\mathrm{S} 10$ & Financial department is the most targeted by computer criminals. & 4.24 & 0.869 & 1 \\
\hline & & $2^{\text {nd }}$ dimension average & 3.848 & 1.013 & - \\
\hline \multirow{5}{*}{$\begin{array}{l}\text { Computer } \\
\text { Ethics At } \\
\text { Work }\end{array}$} & $\mathrm{S} 11$ & I follow computer ethics, when I use computer in my work. & 4.25 & 0.943 & 2 \\
\hline & $\mathrm{S} 12$ & $\begin{array}{l}\text { A manager trust employee who is under a code of computer ethics than } \\
\text { other who is not. }\end{array}$ & 3.78 & 1.079 & 3 \\
\hline & $\mathrm{S} 13$ & $\begin{array}{l}\text { It is easier to find a job if I declare that I act ethically in the professional } \\
\text { environment. }\end{array}$ & 2.92 & 1.286 & 4 \\
\hline & $\mathrm{S} 14$ & It is more secure if the network security is updated frequently. & 4.32 & 0.815 & 1 \\
\hline & & $3^{\text {rd }}$ dimension average & 3.818 & 1.031 & - \\
\hline
\end{tabular}

*SD: Standard deviation

\subsection{Correlation of the dimensions}

The data distribution of the 14 statements of the questionnaire was tested by Kolmogorov-Smirnov, the results of testing shows that the data distribution is not normal. Therefore, Spearman's test for correlation was used to test the correlation between the dimensions of the questionnaire in case of the data distribution is not normal ${ }^{[14]}$. The results are shown in Table 5. The correlation is strong between "studying computer ethics" and "computer ethics at work" with value 0.511 . Furthermore, it is very clear the correlation between "studying computer ethics" and "computer ethics rules and regulations" is strong with value 0.447 . While the correlation between "computer ethics rules and regulations" and "computer ethics at work" is moderate with a value of 0.324 .

From the above it is clear that the weakest correlation was between the dimensions "computer ethics rules and regulations" and "computer ethics at work" due to the lack of strength rules and regulations and the lack of legal cybercrimes rules in Bahrain.

Table 5. Spearman's correlation matrix questionnaire between dimensions

\begin{tabular}{|c|c|c|c|}
\hline Dimension & Studying computer ethics & $\begin{array}{l}\text { Computer ethics rules and } \\
\text { regulations } \\
\end{array}$ & Computer ethics at work \\
\hline Studying computer ethics & 1 & & \\
\hline $\begin{array}{l}\text { Computer ethics rules and } \\
\text { regulations }\end{array}$ & $0.447 * *$ & 1 & \\
\hline Computer ethics at work & $0.511 * *$ & $0.324 * *$ & 1 \\
\hline
\end{tabular}

$* *$. Correlation is significant at the 0.01 level (2-tailed)

\subsection{Hypotheses testing}

The hypotheses $\left(\mathrm{H}_{1}, \mathrm{H}_{2}, \mathrm{H}_{3}\right)$ are tested by simple linea $r$ regression as shown in Table 6 , the first hypothesis $\mathrm{H}_{1}$ : Studying computer ethics have an effect on computer ethics rules and regulations. This hypothesis is related to the first dimension that measures studying computer ethics. The table shows that the coefficient of determination $r$ square equal 
to 0.20 , which indicates that studying computer ethics have a weak effect on computer ethics rules and regulations. In addition, the significance level of $\mathrm{F}$ ( $\mathrm{sig}$ ) equals to 0.000 , which indicates that there is a significant difference between studying computer ethics and computer ethics rules and regulations; which affirms that studying computer ethics have an effect on the computer ethics rules and regulations. The regression equation based on the test is given as:

Computer ethics rules and regulations $=2.34+0.374$ (Studying computer ethics)

These results assure that the studying computer ethics is important to improve and strengthen the commitment of computer ethics rules and regulations.

The second hypothesis of the study $\mathrm{H}_{2}$ : Studying computer ethics have an effect on computer ethics at work. From the table, it is clear that studying computer ethics have a weak effect on computer ethics at work because the coefficient of determination $r$ square value was 0.261 . Moreover, the significance level of $\mathrm{F}(\mathrm{sig})$ value is 0.000 , which indicates that there is a significant difference between studying computer ethics and the computer ethics at work; which affirms that studying computer ethics have an effect on computer ethics at work. The regression equation based on the test is given as:

Computer ethics at work $=1.76+0.509$ (Studying computer ethics)

These results assure that improving studying computer ethics is very important to improve and strengthen computer ethics at work. For example, most of the information technology users assure that the computer ethics study will reduce the computer crimes. In addition, most of them agreed that learning computer ethics is useful in their work. Furthermore, they agreed on the need of studying computer ethics either in universities or by workshops.

The third hypothesis of the study $\mathrm{H}_{3}$ : Computer ethics rules and regulations have an effect on computer ethics at work. The table shows that the coefficient of determination $r$ square value is 0.105 , which indicates that there is a weak effect of computer rules and regulations on computer ethics at work. On the other hand, the significance level of $\mathrm{F}$ (sig) value is 0.000 , which indicates that there is a significance differences between computer ethics rules and regulations and computer ethics at work; which affirms that computer ethics rules and regulations have an effect on computer ethics at work. The regression equation based on the test is given as:

Computer ethics at work $=2.33+0.385$ (Computer ethics rules and regulations)

These results assure computer ethics rules and regulations are very important to improve and strengthen computer ethics at work. For example, commitment to the rules and regulations will reduce computer crimes. Moreover, most of the responds agreed that the only important thing to the professional behavior is the awareness of the law and the ethical aspect is a secondary unless it has legal consequences. Thus, if there are strong rules and regulations toward computer ethics it will have an effect on the computer ethics and will reduce the computer crimes.

Table 6. Regression test for the hypotheses $\mathrm{H}_{1}, \mathrm{H}_{2}, \mathrm{H}_{3}$

\begin{tabular}{|c|c|c|c|c|c|c|c|c|}
\hline Hypothesis & $\begin{array}{c}\text { Source of } \\
\text { variance }\end{array}$ & Sum of squares & $\mathrm{df} *$ & Mean square & $r$ & $r$ square & $\mathrm{F}$ & Sig \\
\hline \multirow{3}{*}{$\mathrm{H}_{1}$} & Regression & 28.899 & 1 & 28.899 & 0.447 & 0.199 & 92.631 & 0.000 \\
\hline & Residual & 116.056 & 372 & 0.312 & & & & \\
\hline & Total & 144.955 & 373 & & & & & \\
\hline \multirow{3}{*}{$\mathrm{H}_{2}$} & Regression & 53.543 & 1 & 53.543 & 0.511 & 0.261 & 131.657 & 0.000 \\
\hline & Residual & 151.286 & 372 & 0.407 & & & & \\
\hline & Total & 204.829 & 373 & & & & & \\
\hline \multirow{3}{*}{$\mathrm{H}_{3}$} & Regression & 21.524 & 1 & 21.524 & 0.324 & 0.105 & 43.680 & 0.000 \\
\hline & Residual & 183.305 & 372 & 0.493 & & & & \\
\hline & Total & 204.829 & 373 & & & & & \\
\hline
\end{tabular}

$\mathrm{df}^{*}$ : Degree of freedom

The hypothesis $\mathrm{H}_{4}$ used to test the effect of demographic information on computer ethics at work. $\mathrm{H}_{4}$ : Demographic information (gender, age, education level, and job position) have statistically significant differences on computer ethics at work. Table 7 shows there is statistically significant difference on computer ethics at work according to gender because the sig value is less than $(\alpha=0.05)$. The result indicates that the average of female in the study were greater than males. This is similar to what Dalton and Ortegren (2011) argued, that a large number of studies find that females report more ethical responses than males and this is corresponding with the result of the this paper. 
Table 7. T-test for gender

\begin{tabular}{ccccccccc}
\hline Dimension & Gender & $\mathrm{N}$ & Mean & SD & Std. error mean & Sig. \\
\hline \multirow{2}{*}{ Computer ethics at work } & Male & 260 & 3.788 & 0.793 & 0.049 & -1.157 \\
& Female & 114 & 3.884 & 0.603 & 0.057 & -1.285 & 0.009 \\
\hline
\end{tabular}

Table 8 shows the results of variance analysis by one way ANOVA according to age, education level, and job postion. The table shows that the age has statistically significant difference on computer ethics at work, because the sig value is less than $(\alpha=0.05)$. Therefore, Scheffe test was used to find the sources of differences between the groups of age. The results of Scheffe test showed that there is no statistically significant differences between age groups and computer ethics at work, the differences between their averages are likely due to chance and not likely due to the independent variable manipulation. The table shows that the education level and job position has no statistically significant differences on the computer ethics at work since the sig values of these dimensions are greater $(\alpha=0.05)$. On the other hand, position has statistically significant influence on computer ethics rules and regulations since the sig value is less than $(\alpha=0.05)$. Therefore, Scheffe test was used to find the sources of differences between the groups of position and computer ethics rules and regulations.

Table 8. Variance analysis for age, education level, and job position

\begin{tabular}{|c|c|c|c|c|c|c|}
\hline \multirow[b]{2}{*}{ Dimension } & \multicolumn{2}{|c|}{ Age } & \multicolumn{2}{|c|}{ Education level } & \multicolumn{2}{|c|}{ Job position } \\
\hline & $\mathrm{F}$ & Sig. & $\mathrm{F}$ & Sig & $\mathrm{F}$ & Sig. \\
\hline $\begin{array}{l}\text { Computer ethics } \\
\text { at work }\end{array}$ & 5.889 & 0.000 & 1.871 & 0.134 & 1.600 & 0.174 \\
\hline
\end{tabular}

\section{Conclusion}

Most of the public and private organization are providing online services to its users to facilitate the use of online services easily and rapidly. This paper evaluated the effect of studying computer ethics and computer ethics rules and regulations on computer ethics at work. A self-administrated questionnaire was designed to employees working in different organizations in Bahrain. According to the opinions of the questionnaire respondents, studying computer ethics early is a must to help the new generation to use computer and internet ethically, as well as the rules and regulations played very important role on computer ethics at work.

Almost all the respondents gave positive responses towards the importance of rules and regulations to reduce computer crimes. The gender and age played an important role on computer ethics at work because, the new generation of employees maybe learned computer ethics either at schools or at colleges. While the level of education level and the job position have no statistically effect, because the employees following regulation of computer ethics at work are very important to employees regardless to their level of education level or job position, therefore they need continuous learning through workshops, to update their information regarding information technology crimes.

According to the results of this study, the study recommended; giving intensively interest in educating employees and increasing their awareness to computer ethics and computer crimes by holding courses and workshops periodically.

\section{References}

[1] Akbulut, Y., Odabaşi F., Kuzu, A. Computer Ethics: Scenes from a Computer Education Department in Turkey, Chapter in Ethical Practices and Implications in Distance Learning. IGI Global. 2009; 295-304. Available from: doi:10.4018/978-1-59904-867-3.ch018.

[2] Arenas, M. Social engineering and internal threats on organizations. Computer Science. 2008.

[3] Australian Government. Australia's 2020 cyber security strategy, commonwealth of Australia. 2019. Available from: https://www.enisa.europa.eu/topics/nis-directive.

[4] Aziz, A., Lokman, A., Yusof, Z. Information technology ethics: the conceptual model of constructs, actions and control measure. International Journal on Computer Science and Engineering. 2011; 3(6): 2580-2588.

[5] Ben-Jacob, M. Integrating computer ethics across the curriculum: a case study. Educational Technology \& Society. 2005; 8(4): 198-204.

[6] Bynum, T. Computer and Information Ethics. 2008. Available from: http://plato.stanford.edu/archives/win2014/ entries/ethics-computer. 
[7] Bynum, T. W., Rogerson, S. Computer ethics and professional responsibility. Oxford UK: Blackwell Publishing; 2004.

[8] Capurro, R., Britz, J. B. In search of a code of global information ethics: the road travelled and new horizons. Ethical Space: International Journal of Communication Ethics. 2010; 7(2): 28-36.

[9] CBB. Announcement. 2019. Available from: Central Bank of Bahrain: http://www.cbb.gov.bh/ar/page_1.php?p=\%D8 $\%$ A8\%D9\%8A\%D8\%A7\%D9\%86_\%D8\%B5\%D8\%AD\%D9\%81\%D9\%8A.

[10] Chaudhary, G. Development review on phishing: a computer security threat. International Journal of Advance Research in Computer Science and Management Studies. 2014; 2(8): 55-64.

[11] Cummings, A., Lewellen, T., McIntire, D., Moore, A. P., Trzeciak, R. F. Insider threat study: Illicit cyber activity involving fraud in the U.S. financial services sector. Technical, Carnegie Mellon University, Software Engineering Institute. 2012.

[12] Dalton, D., Ortegren, M. Gender differences in ethics research: the importance of controlling for the social desirability response bias. Journal of Business Ethics. 2011; 103(1): 72-93.

[13] Davis, S. Is your company managing data effectively? Premium Magazine. 2013. Available from: http://www. premium-me.com.

[14] Devore, J., Farnum, N., Doi, J. Applied statistics for engineers and scientists. USA: Cengage Learning; 2013.

[15] Dolado, J. Is it worthwhile to teach computer ethics. In: E. Georgiadou, G. King, P. Pouyioutas, M. Ross, G. Staples, Inspire V. (eds.) Quality and software development: teaching and training issues. UK: The British Computer Society; 2000 .

[16] Fanning, E. Formatting a paper-based survey questionnaire: best practices. Practical Assessment Research \& Evaluation. 2005; 10(12): 1-14.

[17] Fatima, A. E-banking security issues-is there a solution in biometrics? Journal of internet banking and commerce. 2011; 16(2): 1-9.

[18] Franzke, A., Bechmann, A., Zimmer, M., Ess, C., the association of internet researchers. Internet Research: Ethical Guidelines 3.0. 2020. https://aoir.org/reports/ethics3.pdf.

[19] Gartner. Hyper cycle privacy. 2019. Available from: https://www.gartner.com/en/documents/3947373.

[20] Johnson, D. G. Computer ethics. Englewood: Prentice-Hall; 1985.

[21] Kizza, J. Ethical and social issues in the information age. London: Springer; 2013.

[22] Knox, J. Identity theft and identity fraud. 2014. Available from: The United States Department of Justice: http://www. justice.gov/criminal/fraud/websites/idtheft.html.

[23] Kroger, D. J., Sena, M. P. An MBA course in rthics, security, and privacy. San Antonio, USA: AITP Foundation for Information Technology Education; 2002. p.254-258. Available from: http://proc.isecon.org/2002/254a/ISECON.2002. Kroger.pdf.

[24] Kuzu A. Problems related to computer ethics: origins of the problems and suggested solutions. Turkish Online Journal of Educational Technology. 2009; 8(2): 91-110.

[25] Lim, J., Hwa, N. K. Computer fraud and ethics: the societe generale's trading fraud. IEEE international conference on computer and management. Wuhan, China; 2011.

[26] Magnin, C. J. The 2001 council of europe convention on cyber-crime: an efficient tool to fight crime in cyber-space. Santa Carla University, USA; 2001.

[27] Microsoft. Microsoft Security Intelligence Report. 2014. Available from: Microsoft: http://www.microsoft.com/ security/sir/default.aspx.

[28] Moor, J. What is Computer Ethics? Metaphilosophy. 1985; 16(4): 266-275.

[29] Moores, T., Dhillon, G. Software Piracy: a View from Hong Kong. Communications of the ACM. 2000 ; 43 : 88-93.

[30] Norton. Norton Report. Norton by Symantec. 2013. Available from: http://www.symantec.com/about/news/resources/ press_kits/detail.jsp?pkid=norton-report-2013/.

[31] Orgill, G. L., Romney, G. W., Bailey, M. G. Orgill, P. M. The urgency for eEffective user privacy-education to counter social engineering attacks on secure computer systems. Salt Lake City: ACM; 2004.

[32] Pardesi, J. Emerging Trends in Information Technology. Nirali Prakashan; 2007.

[33] Rathinasabapathy, G., Rajendran, L. Cyber crimes and information frauds: emerging challenges for LIS professionals. In information to knowledge: technology and professionals. Proceedings of the Conference on Recent Advances in Information Science and Technology. Kalpakkam: MALA and IGCAR; 2007. p.131-142.

[34] Ryu, Y. Development of usability questionnaires for electronic mobile products and decision making methods. Virginia, USA; 2005.

[35] Seger, A. Cyber crime and economic crime. In: M. Edelbacher, P. Kratcoski, M. Theil. (eds.) Financial crimes: A Tthreat to global security. New York: CRC Publishing; 2012.

[36] Sembok, T. Ethics of Information Communication Technology. Regional unit for social and human sciences in asia 
and the pacific, unesco. 2004; 239-325.

[37] Singh, S., Gupta, P. Cyber Crime and Legal Issues. In: K. Jaishankar, N. Ronel. (eds.) Proceedings of the second international conference of the south asian society of criminology and victimology. India; 2013. p.437-439.

[38] Stewart, J., Tittle, E., Chapple, M. Cissp: Certified information system security professional study guide. Wiley Publishing, Inc; 2012.

[39] Stückelberger, C., Duggal, P. Cyber ethics 4.0 serving humanity with values, globethics. Net Global Series. 2018.

[40] Suja, P., Nirmala, R. Cybercrime in banking sector. International Journal of Research in Social Sciences. 2014; 4(1): 189-194.

[41] Tzafestas, S. Ethics and law in the internet of things world, smart cities. 2018; 1: 98-120. Available from: doi: 10.3390/smartcities 1010006.

[42] UNODC. Comprehensive Study on Cybercrime. Vienna: United Nations; 2013. Available from: http://www.unodc.org/ documents/organized-crime/UNODC_CCPCJ_EG.4_2013/CYBERCRIME_STUDY_210213.pdf.

[43] Wang, R. Relationship, Loyalty, and Marketing-A Correlation Study of Taiwan Hotel Customers' Perspectives. Oklahoma, USA; 2007.

[44] Pearson's r Correlation. 2015. Available from: http://faculty. Quinnipiac.edu/libarts/polsci/Statistics.html. 